\title{
BROOMRAPE SEED GERMINATION ON NUTRITIVE MEDIA AND POSSIBILITY OF ITS BIOLOGICAL CONTROL
}

Maširević, S. ${ }^{*}$, Medić-Pap, S. ${ }^{2}$, Terzić, A. ${ }^{1}$

${ }^{1}$ Faculty of Agriculture, Trg Dositeja Obradovića 8, 21000 Novi Sad, Serbia,

${ }^{2}$ Grantee of Ministry of Education and Science, Belgrade, Republic of Serbia

Received: November 10, 2012

Accepted: December 10, 2012

\section{SUMMARY}

In tests of sunflower hybrids' susceptibility to broomrape under artificial inoculation conditions, a high germination rate of broomrape seed used for infestation is prerequisite. On the other hand, one of the ways to reduce the great potential of broomrape seeds is biological control.

Seed germination was evaluated on three different media. The first medium was water agar with giberellic acid (GA3) and presence of roots of the susceptible sunflower hybrid NS-H-111. The medium for the evaluation of influence of the biological agent on seed germination was the same with bioagent Trifender added in concentration of $1 \%$. The check was a medium with GA3 only. Seeds of Orobanche cumana were collected in sunflower fields in Vojvodina at five different localities. The seeds were placed in Petri dishes with nutritive media and incubated at $25^{\circ} \mathrm{C}$ in the dark. Germination rate, germ length and distance of germinated broomrape seed from sunflower root were determined at 7 day intervals under the dissecting microscope.

After 28 days on the GA3 medium with sunflower roots broomrape seeds germinated at the rate of $44-68 \%$, while on media with Trifender they had significantly lower germination (4-41\%). There was no broomrape seed germination on water agar with GA3 only in any sample. Germ lengths of seeds on the GA3+sunflower roots media were significantly longer than those on the medium with Trifender. Orobanche seed which were closer to the sunflower root had better germination on both media.

\section{Key words: broomrape, seed germination, biological control, Trichoderma} asperellum

\section{INTRODUCTION}

Broomrape (Orobanche cumana) is one of the most important harmful parasites of sunflower. It occurs with varying intensity almost every year in the agroeco-

* Corresponding author: e-mail: stevanm@polj.uns.ac.rs 
logical conditions of Serbia and can cause significant damage in sunflower production (Gulya et al., 1997, Maširević, 2002). Yield losses depend on the severity of the attack and can range from 5 to 100\% (Maširević, 2001). The broomrape genus (Orobanche L.) is characterized by pronounced biodiversity. Approximately 200 Orobanche species have been reported worldwide (Pusch and Günther, 2009). In Serbia there are 26 different broomrape species, 56 varieties, and 226 forms, making up a total of 308 different taxa (Maširević and Kojić, 2006). Among these, the most dangerous to sunflower is O. cumana Wallr. (sin. O. cernua Loef.). Sunflower is also parasitized by the broomrape species $O$. coerulescens, O. minor, $O$. ramosa, O. brassicae, O. aegyptica and O. crenata. The last two of these have not been reported in Serbia.

In addition to this pest's huge infectious potential, another great problem is caused by the heterogeneity of its population, i.e., by the existence of multiple physiological races, each specific to a particular sunflower region. The appearance of new broomrape races has been reported in recent years in countries such as Romania, Bulgaria, Turkey, Spain, and Russia (Škorić et al., 2010). According to our analysis, race $\mathrm{E}$ is the dominant form in Serbia (Maširević and Medić-Pap, 2009). However, there have been some changes in the racial composition of the broomrape population in Serbia (Maširević et al., 2012). Resistant or tolerant sunflower hybrids are the most efficient and most economical measure in the suppression of this parasitic plant.

In tests of sunflower hybrids' susceptibility to broomrape under artificial infestation conditions, a high germination rate of broomrape seed used for infestation is prerequisite. On the other hand, the key to improved sunflower production in natural infested areas, beside growing resistant hybrids, is a reduction in the enormous amount of seeds in the soil. One of the ways to reduce such great seed potential is biological control.

The aim of this paper is to evaluate the influence of sunflower roots and the biological agent Trifender on broomrape seed germination on nutritive media. Trifender is a biological pesticide containing the fungus Trichoderma asperellum that acts as a plant growth promoter with the beneficial side effect of being able to control soil borne pathogens when incorporated into soil. Because of the method of its application Trifender is suitable for broomrape control.

Table 1: Broomrape seed samples used in test

\begin{tabular}{lcc}
\hline \multirow{2}{*}{ Locality } & \multicolumn{2}{c}{ Sample number } \\
\cline { 2 - 3 } & GA3+roots & GA3+T+roots \\
\hline Bačka Topola & $1 \mathrm{GA}$ & $1 \mathrm{~T}$ \\
Vršac & $2 \mathrm{GA}$ & $2 \mathrm{~T}$ \\
Svetozar Miletić & $3 \mathrm{GA}$ & $3 \mathrm{~T}$ \\
Vatin & $4 \mathrm{GA}$ & $4 \mathrm{~T}$ \\
Zrenjanin & $5 \mathrm{GA}$ & $5 \mathrm{~T}$ \\
\hline
\end{tabular}




\section{MATERIALS AND METHODS}

Seeds of Orobanche cumana were collected during 2009 in sunflower fields in Vojvodina at five different localities (Table 1, Figure 1).

Seed samples were kept in the fridge at $+4^{\circ} \mathrm{C}$ in order to break dormancy and stimulate germination. Seed germination was evaluated on three different media. The first medium was water agar with giberellic acid (GA3, Sigma-Aldrich, USA) in concentration of $25 \mathrm{ppm}$ and presence of 5-8 days old roots of the susceptible sunflower hybrid NS-H-111 (Figure 2). In previous preliminary investigations the medium had proven good for provoking broomrape seed germination (Maširević et al., 2011). The medium for evaluating the influence of biological agent on seed germination was the same with Trifender ( $\mathrm{T}$ ) added in concentration of $1 \%$. The check was water agar with GA in concentration of $25 \mathrm{ppm}$.

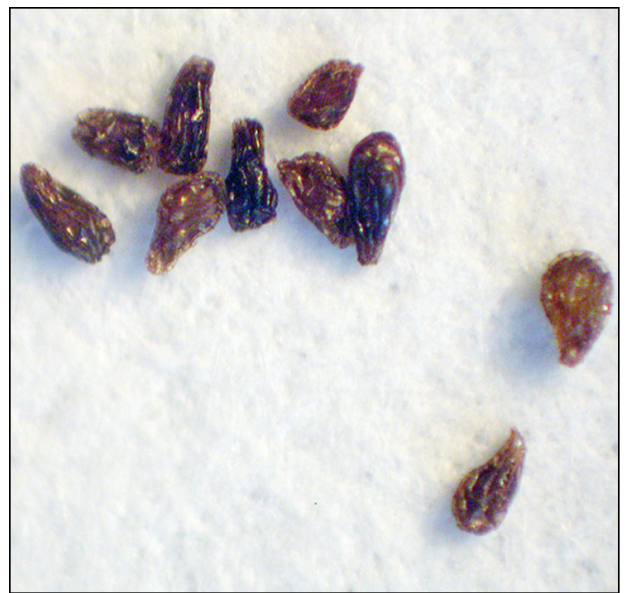

Figure 1: Broomrape seed (Orobanche cumana)

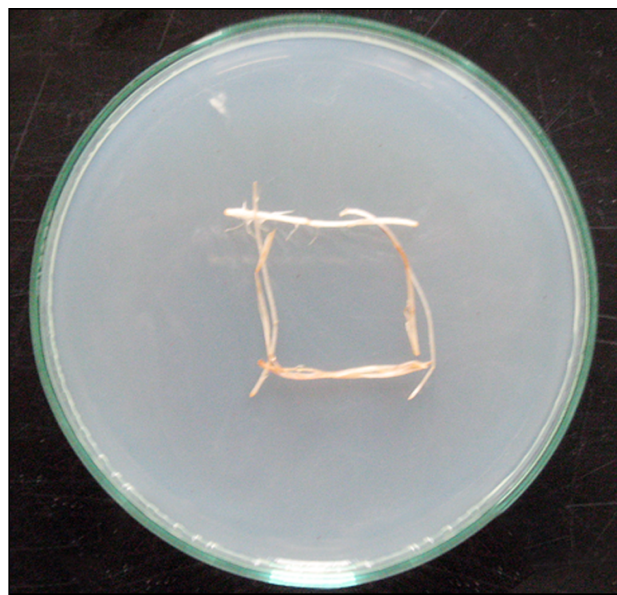

Figure 2: Nutritive media with sunflower roots

Surface sterilized seeds were placed in Petri dishes with nutritive media and incubated at $25^{\circ} \mathrm{C}$ in the dark. For each seed sample and medium 25 seeds in 4 replicates were used. Broomrape seeds were placed at different distances from the sunflower root in order to evaluate the effect of the vicinity of sunflower root on broomrape germination. Germination rate, germ length and distance of germinated broomrape seed from the sunflower root were determined after 7, 14, 21 and 28 days under the dissecting microscope. Data were analyzed by ANOVA and Duncan test using the Statistica 10 software.

\section{RESULTS AND DISCUSSION}

The seed of parasitic weeds germinate only if they are exposed to stimulant molecules which are present in the root exudate of a suitable host plant (Mussel- 
man, 1987; Parker and Riches, 1993). It has been widely reported that for germination under chemical stimulation Orobanchaceae seeds required conditioning for several days in a wet environment and at suitable temperatures (Pieterse, 1979; Press et al., 1990; Chae et al., 2003). However, the recent results of Plakhine et al., 2009 and Plakhine and Joel, 2010, showed that non-conditioned seeds of both Orobanche cumana Wallr. and O. aegyptiaca Pers. were able to germinate in response to chemical stimulation by GR24 even without prior conditioning.

This paper evaluates the influence of young roots of susceptible hybrids on broomrape seed germination in vitro. After 7 days on media with GA3 and sunflower roots broomrape seeds germinated at the rate of 33-61\% depending on locality. Broomrape seeds from Zrenjanin had the best germination rate. There was no significant difference between seeds from other localities on the GA3 medium+roots. After 7 days seeds from Svetozar Miletić germinated in the highest percentage on media with Trifender, while the other seed samples had low germination. After 28 days on media with GA3 and sunflower roots broomrape seeds germinated at the rate of $44-68 \%$ depending on locality (Table 2 ).

Table 2: Comparison of broomrape seed germination rate after 7 and 28 days

\begin{tabular}{|c|c|c|c|c|}
\hline \multirow{3}{*}{$\begin{array}{l}\text { Broomrape } \\
\text { seed sample }\end{array}$} & \multicolumn{4}{|c|}{ Germination rate (\%) } \\
\hline & \multicolumn{2}{|c|}{7 days } & \multicolumn{2}{|c|}{28 days } \\
\hline & 61 & $a$ & 68 & $\mathrm{a}$ \\
\hline $3 \mathrm{GA}$ & 51 & $a b$ & 65 & $a$ \\
\hline $1 \mathrm{GA}$ & 40 & $b$ & 54 & $a b$ \\
\hline $2 \mathrm{GA}$ & 37 & $\mathrm{~b}$ & 51 & $a b$ \\
\hline $4 \mathrm{GA}$ & 33 & $b$ & 44 & $b$ \\
\hline $3 \mathrm{~T}$ & 31 & $\mathrm{bc}$ & 41 & $b$ \\
\hline $1 \mathrm{~T}$ & 14 & $\mathrm{~cd}$ & 39 & $b$ \\
\hline $2 \mathrm{~T}$ & 10 & $\mathrm{~d}$ & 13 & $\mathrm{c}$ \\
\hline $5 \mathrm{~T}$ & 7 & $d$ & 15 & $\mathrm{C}$ \\
\hline $4 \mathrm{~T}$ & 2 & $\mathrm{~d}$ & 4 & C \\
\hline $\bar{p}$ & \multicolumn{2}{|c|}{0.000002} & \multicolumn{2}{|c|}{0.000000} \\
\hline
\end{tabular}

On nutritive media with Trifender the seed samples from Bačka Topola and Svetozar Miletić had a relatively high percentage of germination (41 and 39\%, respectively), while seed samples from the other three localities had significantly lower germination (15, 13 and 4\%) compared to seeds on basic media (Figure 3).

Given that Bačka Topola and Svetozar Miletić are among the localities that are the main foci of broomrape distribution in Vojvodina, such germination despite the bio-agent could be explained by high seed vitality and virulence of the population in these regions. There was no broomrape seed germination on water agar with only GA3 medium in any sample. Nutritive media without sunflower could not provoke germination of broomrape seeds. Glijin et al. (2011) investigated the effect of root exudation from different sunflower genotypes on broomrape seed germination. They recorded the highest seed germination in one of the most virulent races stimulated by root exudates of a differential line (70\%). The same authors observed that 
seeds of Orobanche cumana germinate only in the presence of sunflower roots. Presence of roots of susceptible sunflower hybrids stimulated broomrape seed germination in vitro. This phenomenon could be used in field experiments to increase the pressure on the tested material. In the resistance test, during sowing, along with sunflower seed and inoculum (broomrape seed) the roots of susceptible hybrids should be added.

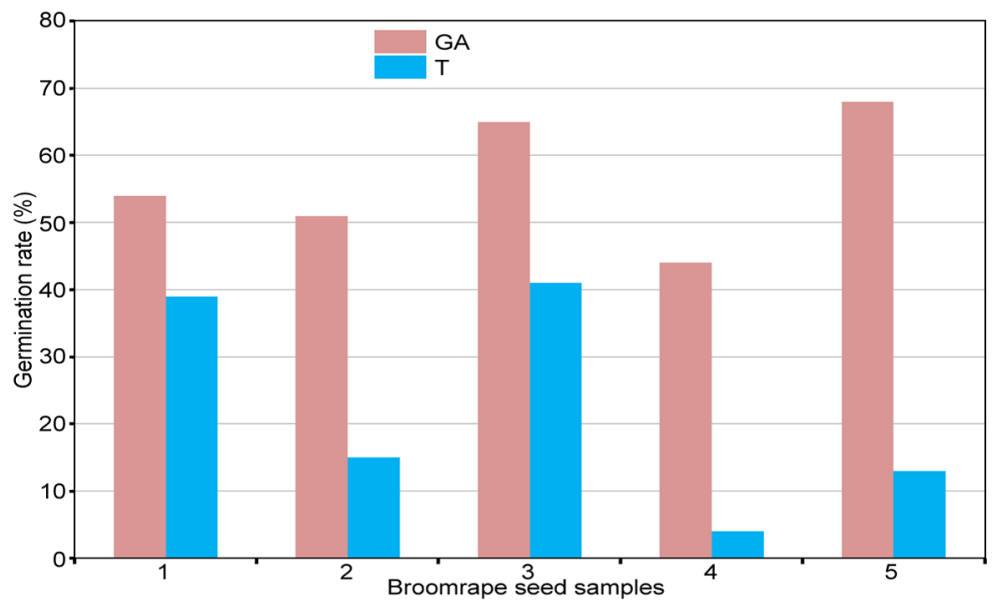

Figure 3: Comparison of broomrape seed germination rate on different media after 28 days.

In all the samples germ lengths of seeds on media with GA3 and roots were significantly longer than those observed on media with Trifender. Average broomrape length on basic media was $0.96 \mathrm{~mm}$, while on media with Trifender it was $0.36 \mathrm{~mm}$ (Table 3).

Table 3: Comparison of broomrape germ length on different media after 28 days

\begin{tabular}{lcc}
\hline Broomrape seed sample & \multicolumn{2}{c}{ Germ length $(\mathrm{mm})$} \\
\cline { 2 - 3 } & GA3+roots & T+GA3+roots \\
\hline Bačka Topola & $0.98 \mathrm{a}$ & $0.36 \mathrm{~b}$ \\
Vršac & $0.97 \mathrm{a}$ & $0.45 \mathrm{~b}$ \\
Svetozar Miletić & $1.04 \mathrm{a}$ & $0.35 \mathrm{~b}$ \\
Vatin & $0.83 \mathrm{a}$ & $0.39 \mathrm{~b}$ \\
Zrenjanin & $1.03 \mathrm{a}$ & $0.26 \mathrm{~b}$ \\
average & 0.97 & 0.36 \\
\hline $\mathrm{p}$ & & \\
\hline
\end{tabular}

From the obtained results it can be concluded that Trifender inhibited not only germination but also germ growth. Joel (2000) suggested that new practical control measures of these root parasites can be based either on germination inhibition or on the promotion of suicidal germination in the absence of a host, thus depleting the soil of Orobanche seeds.

The influence of close vicinity of sunflower roots on germinated broomrape seeds after 7 and 14-28 days was evaluated (Table 4 and Figure 4). Based on aver- 
age data (Table 4) it can be concluded that seeds which were closer to the sunflower root germinated faster. The average distance of germinated broomrape seeds from sunflower roots on Trifender after 7 days was $8.5 \mathrm{~mm}$, while on media without Trifender it was $11.9 \mathrm{~mm}$. The same tendency was present in the period from 14 to 28 days. Although there was a difference in distances in the second period (14-28 days), that difference was not statistically significant.

Table 4: Comparison of distance of germinated broomrape seed from sunflower root after 7 and 14-28 days

\begin{tabular}{|c|c|c|c|c|}
\hline \multirow{3}{*}{$\begin{array}{l}\text { Broomrape } \\
\text { seed sample }\end{array}$} & \multicolumn{4}{|c|}{ Average distance of broomrape germinated seed from sunflower root (mm) } \\
\hline & \multicolumn{2}{|c|}{7 days } & \multicolumn{2}{|c|}{ 14-28 days } \\
\hline & GA+roots & $\mathrm{T}+\mathrm{GA}+$ roots & $\mathrm{GA}+$ roots & $\mathrm{T}+\mathrm{GA}+$ roots \\
\hline Bačka Topola & $14.2 \mathrm{ab}$ & $16.1 \mathrm{a}$ & $14 \mathrm{ab}$ & $12.2 \mathrm{ab}$ \\
\hline Vršac & 7.1 cde & 4.1 & $12 a b$ & $8.4 \mathrm{ab}$ \\
\hline Svetozar Miletić & $10.5 \mathrm{abcd}$ & 8.8 bcde & $10 \mathrm{ab}$ & $13.3 \mathrm{ab}$ \\
\hline Vatin & $15.2 \mathrm{ab}$ & 2.6 & $18.1 \mathrm{a}$ & $4.6 \mathrm{~b}$ \\
\hline Zrenjanin & $12.5 \mathrm{abc}$ & $11.1 \mathrm{abc}$ & 12.2ab & $9.8 \mathrm{ab}$ \\
\hline average & 11.9 & 8.5 & 13.3 & 9.7 \\
\hline$p$ & \multicolumn{2}{|c|}{$0.0005^{*}$} & \multicolumn{2}{|c|}{$0.2698 \mathrm{~ns}$} \\
\hline
\end{tabular}

If the samples are analyzed separately it can be noticed that in five samples broomrape seeds germinated faster if they were closer to the sunflower roots, whereas in three samples the distance from the roots had no influence on germination. In two samples the seeds which were farther away from sunflower roots germinated faster (Figure 4), but the differences between the two measured periods were only up to $2-3 \mathrm{~mm}$. The average distance of germinated broomrape seeds from the sunflower root did not exceed $18 \mathrm{~mm}$.

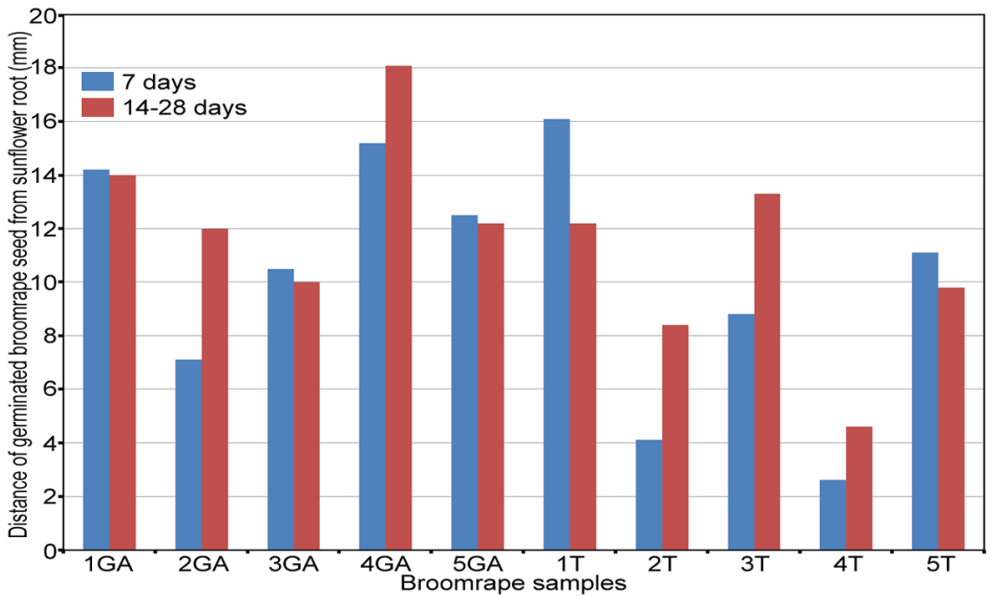

Figure 4: Comparison of distance of germinated broomrape seeds from sunflower root after 7 and 14-28 days

Joel et al. (2011) reported that at a distance of 1-2 cm from the sunflower roots, where germination is normally lower (than between the roots), the broomrape seeds did not germinate at all in a phosphate deprived system. 


\section{CONCLUSION}

These results indicate that roots of susceptible sunflower genotypes stimulate germination of broomrape seed in vitro. However, differences in germination between populations were obtained. This phenomenon could be used in field experiments for better induction of broomrape seed germination in the resistance test. Fresh wet roots 5-8 days old could be used as carrying agents of broomrape seed and placed together with sunflower seedbed. The roots will stimulate broomrape seed germination and this will lead to increased pressure of the parasite on the plant.

The bio-agent based on T. asperellum inhibited germination of broomrape in vitro. The inhibition was in the form of a lower germination rate and shorter germ length. In the experiment differences in population responses to the applied bioagent were obtained. The effect of this bio-pesticide on broomrape seed germination should be further investigated in field conditions.

\section{ACKNOWLEDGEMENT}

This paper was realized as part of the project "Studying climate change and its influence on the environment: impacts, adaptation and mitigation" (43007), financed by the Ministry of Education and Science of the Republic of Serbia within the framework of integrated and interdisciplinary research for the period 2011-2014.

\section{REFERENCES}

Chae, S.H., Yoneyama, K., Takeuchi, Y. and Joel, D.M., 2003. Fluridone and norflurazon, carotenoid-biosynthesis inhibitors, promote seed conditioning and germination of theholoparasite Orobanche minor. Physiol Plant 120: 328-337.

Glijin, A., Acciu, A. and Mita, E., 2011. Effect of root exudation from different sunflower genotypes on broomrape seed germination. International Symposium on Broomrape (Orobanche spp.) in sunflower. 25-27 August, Chisinau Moldova, 23.

Gulya, T., Rashid, K. and Maširević, S., 1997. Sunflower diseases. In: Sunflower Technology and Production (Schneiter, A., ed.). American Society of Agronomy, Madison, Wisconsin, USA, pp. 834 .

Joel, D.M., 2000. The long-term approach to parasitic weeds control: manipulation of specific developmental mechanisms of the parasite. Crop Protect. 19: 753-758.

Joel, D.M., Chaudhurib, S.K., Plakhine, D., Ziadna. H. and Steffensb, J.C., 2011 . Dehydrocostus lactone is exuded from sunflower roots and stimulates germination of the root parasite Orobanche cumana Phytochemistry 72(7): 624-634.

Maširević, S., 2001. Širenje volovoda na suncokretu i analiza populacije parazita. Zbornik radova Naučnog Instituta za ratarstvo i povrtarstvo, Novi Sad. Sveska 35: 235-241.

Maširević, S. and Kojić, M., 2002. Rasprostranjenje i biodiverzitet volovoda (Orobanche L.) u Evropi i kod nas. Zbornik radova Naučnog Instituta za ratarstvo i povrtarstvo, Novi Sad. Sveska 36: 161-168.

Maširević, S. and Medić-Pap, S., 2009. Status of broomrape in Serbia from the occurence up to now-days. Helia 32(51: 91-100. 
Maširević, S., Medić-Pap, S., Konstantinović, B. and Terzić, A., 2011. Germination of broomrape seed on different nutritive media. $11^{\text {th }}$ World Congress on Parasitic Plants, 7-12 June, Martina Franca, Italy, 68.

Maširević, S., Medić-Pap, S., Škorić, D., 2012. Is there appearance of new broomrape race in Serbia? $18^{\text {th }}$ Conference on Sunflower, Argentina. (In press)

Musselman, L.J., 1987. Parasitic Weeds in Agriculture. Volume I. Striga. Boca Raton, Florida: CRC Press pp. 317.

Parker, C. and Richesn, C.R., 1993. Parasitic Weeds of the World: Biology and Control. Wallingford, UK, CAB International.

Pieterse, A.H., 1979. The broomrapes (Orobanchaceae) - a review. Abst Trop. Agric. 5: 9-35.

Plakhine, D. and Joel, D., 2010. Ecophysiological consideration of Orobanche cumana germination. Helia 33(52): 13-18.

Plakhine, D., Ziadna, H., Joel, D., 2009. Is seed conditioning essential for Orobanche germination? Pest Management Science Special Issue: OECD: Managing Parasitic Weeds 65(5): 492-496.

Press, M.C., Graves, J.D. and Stewart, G.R., 1990. Physiology of the interaction of angiosperm parasites and their higher plant hosts. Plant Cell Environ. 13: 91-104.

Pusch, J. and Gunther, K.F., 2009. Orobanchaceae (Sommerwurzgewächse). In: G. Hegi (ed.), Illustrierte Flora von Mitteleuropa Bd. 6/1A, Lieferung 1.Weissdorn-Verlag, Jena.

Škorić, D., Pacureanu-Joita, M., Elizabeta, S., 2010. Sunflower breeding for resistance to broomrape (Orobanche cumana Wallr.). An. N.C.D.A. Fundulea, Bucharest, Romania. Vol. LXXVIII (1): 63-79. 